\title{
Neoplatonism in the Cologne tradition of the later Middle Ages: Berthold of Moosburg (ca. 1300-1361) as case study
}

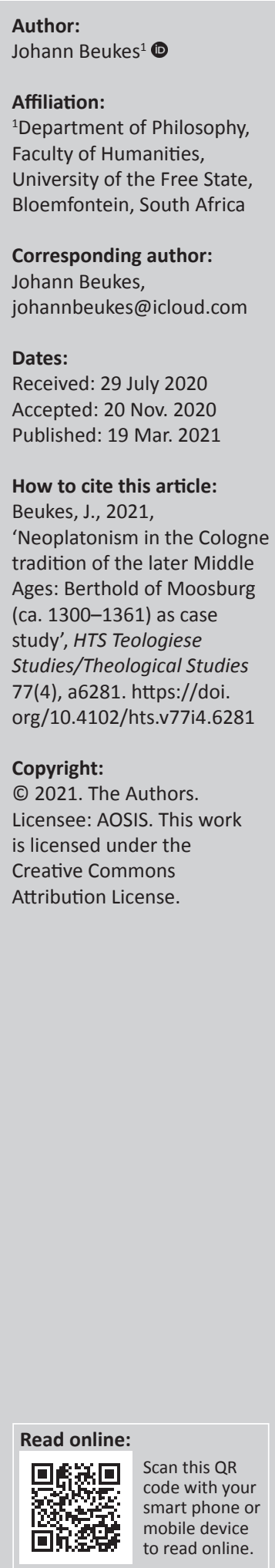

The objective of this article is to present an overview, based on the most recent specialist research, of Neoplatonist developments in the Cologne tradition of the later Middle Ages, with specific reference to a unique Proclian commentary presented by the German Albertist Dominican, Berthold of Moosburg (ca. 1300-1361). Situating Berthold in the post-Eckhart Dominican crisis of the 1340s and 1350s, his rehabilitating initiative of presenting this extensive (nine-volume) commentary on the Neoplatonist Proclus Lycaeus' (412-485) Elements of Theology in his Expositio super Elementationem theologicam Procli, the only of its kind from the Middle Ages, is contextualised with reference to Berthold's discursive indebtedness to his Dominican predecessors, Albert the Great (ca. 1200-1280), Ulrich of Strasbourg (ca. 1220-1277) and Dietrich of Freiberg (ca.1250 - ca.1310), as well as two Dutch-Cologne successors, the Albertist Heymeric of Camp (1395-1460) and the Carthusian Thomist Denys de Leeuwis (1402-1471). Berthold's unique contribution to the philosophical discourse of the Middle Ages is indicated therein that the Expositio provided a synthesis of the late Medieval version of Neoplatonism and contemporaneous German-Dominican theories. By contextualising the work of his Cologne predecessors and successors in the broad idea-historical landscape of antiquity and Neoplatonism, the article argues that Berthold succeeded in linking the Neoplatonic legacy with Cologne Albertism and provided an impetus for the overall consolidating ability of the Cologne tradition. By juxtaposing Berthold and his Expositio with the more conventional legacies of Ulrich, Dietrich, Heymeric and Denys, this exceptional Latin-Western intellectual tradition from Cologne is expanded and enriched with regard to its notable Neoplatonic contributions to philosophy in the later Middle Ages.

Contribution: This article contributes to scholarship in Medieval philosophy by presenting an overview of Neoplatonist developments in the Cologne tradition of the later Middle Ages, with specific reference to the Proclian commentary presented by the German Albertist Dominican, Berthold of Moosburg (ca. 1300-1361). By contextualising the work of Berthold's Cologne predecessors and successors in the broad idea-historical landscape of antiquity and Neoplatonism, the article indicates that Berthold succeeded in linking the Neoplatonic legacy with Cologne Albertism and provided an impetus for the overall consolidating ability of the Cologne tradition during the later Middle Ages.

Keywords: Albert the Great (ca. 1200-1280); Albertism; Berthold of Moosburg (ca. 1300-1361); Denys de Leeuwis (1402-1471); Dietrich of Freiberg (ca.1250-ca.1310); Dominican studium generale Cologne; Expositio super Elementationem theologicam Procli; Heymeric of Camp (1395-1460); Proclus Lycaeus (412-485); Ulrich of Strasbourg (ca. 1220-1277).

\section{The Cologne tradition of the later Middle Ages and the legacy of Albert the Great (ca. 1200-1280)}

The objective of this article is to present an overview, based on the most recent specialist research, of Neoplatonist developments in the Cologne tradition of the later Middle Ages, with specific reference to the unique Proclian commentary presented by the German Albertist Dominican, Berthold of Moosburg (ca. 1300-1361). The article is descriptive-analytical in its presentation of the relevant history of ideas and synthetical in its attempt to coherently integrate the most recent secondary texts on the relevant philosophical themes. Berthold is pertinently situated in the post-Eckhart Dominican crisis of the 1340s and 1350s, with focus on his rehabilitating initiative of presenting an extensive (nine-volume) commentary on the Neoplatonist Proclus Lycaeus' (412-485) Elements of Theology (Institutio Theologica) in Expositio super Elementationem theologicam Procli, the only Proclian commentary from the Middle Ages. Berthold is furthermore contextualised 
with reference to a discursive indebtedness to his Dominican predecessors, Albert the Great (Albertus Magnus, ca. 12001280), Ulrich of Strasbourg (ca. 1220-1277) and Dietrich of Freiberg (ca. 1250-ca.1310), as well as two Dutch-Cologne successors, the Albertist Heymeric of Camp (1395-1460) and the Carthusian Thomist Denys de Leeuwis (1402-1471).

The 'Cologne tradition' (also referred to as the 'Cologne school', cf. Führer 1999:69-70) refers to idea-historical developments within the Dominican studium generale in Cologne, established in 1248 in the historic German city (the former Roman Colonia Claudia Ara Agrippinensium) by the Dominican Albert the Great, assisted by his young student from the same mendicant order, Thomas Aquinas (1225-1274). This tradition incorporated the ongoing development of the studium's initial interests at the University of Cologne, established more than a century later (in 1388, Universitas Coloniensis). The Cologne tradition was, therefore, inevitably Albertist in its initial orientation within late Medieval Aristotelianism, in the sense that Albert was interpreted and represented as the most erudite and informed commentator of Aristotle in the 13th century. This Albertist positioning, in terms of Albert's distinct reception ${ }^{1}$ of Aristotle, resisted later developments in Thomism (referring to the influence of Aquinas), Scotism (the Franciscan trajectory embedded in the work of John Duns Scotus, ca. 1266-1308) and nominalism (the 14th-century critique of realism by probably the most influential thinker of that century, the Franciscan William of Ockham, ca. 1285-1349).

Albert joined the young Dominican order between 1223 and 1229, which was established only years before by Dominic (1170-1221) in Toulouse before rapidly expanding throughout Europe, sanctioned by several papal bulls since its foundation. Albert completed his admission to the order with distinction in Cologne, after which the Dominicans sent him to join the Faculty of Theology in Paris for advanced study in 1240. Older than his fellow students (at least 40 at the time), Albert made swift progress and had the academic world in Paris at his feet in the 1240s, having read and meticulously commented the full extant Aristotelian corpus, in spite of both private and public readings of Aristotle being prohibited in Paris within two decades of it becoming available in Latin around 1210. By the time Albert's commentaries were made public, they represented the most extensive interpretations of Aristotle in any language; in fact, Albert wrote two independent commentaries on some Aristotelian texts. Furthermore, Albert showed an intense interest in thinkers he considered to have thematically overlapped with Aristotle or had greatly clarified Aristotle's thought in his opinion (one of the Dominicans' preferred sources, Pseudo-Dionysus, ca. 500; cf. Beukes 2018a:1-3, amongst others), writing extensively on these Medieval predecessors as well. These commentaries on Aristotle and Aristotelian thinkers eventually comprised 40 volumes. Albert also wrote

\footnotetext{
1.See Aertsen (1996:111-128, 2013:611-618); Anzulewicz (2013a:325-346, 1.See Aertsen (1960). Bertolacci (2013:601-610). B An (2001:15-21). Copleston (1993:293-301); Dreyer (2006:92-101); Heiduk (2012:6-22); Hendrix (2010:1-8); Mahoney (1982:602-622); Noone (2013:543-552); Resnick (2013:1-14); Synan Mahoney (1982:602-622); Noone (2013:543-552); Resnick (2013:1-14); Synan
(1980:1-12); Tracey (2013:347-380); Twetten and Baldner (2013:165-172); (1980:1-12); Tracey (2013:347-380); Twetten
Weisheipl (1980:13-52) and Zambelli (1992:43-74).
}

comprehensive commentaries on the texts of both the Old and New Testament, supplemented by a considerable commentary on Peter Lombard's (1095-1160) Sententiae in quatuor IV libris distinctae. These theological commentaries contained an additional 30 volumes. By the late 1250s, Albert was as an author consequently in control of 70 volumes of academic work. The astonishing scope as such was nevertheless not the most striking feature of his oeuvre; it was precisely the quality of the academic erudition reflected therein, which justified its almost immediate prestige.

The Nicomachus was the first Aristotelian text engaged by Albert, with two independent and non-related systems of exegesis and commentaries on the text. The remainder of the 40 volumes followed over the next two decades. Albert implemented Aristotle's division of the philosophical branches of knowledge or the 'sciences' (in the Medieval sense) without objection nor modification, maintaining the distinction between speculative and practical philosophy, the first being subdivided into natural philosophy, mathematics and metaphysics Albert (1960). Practical philosophy, on the other hand, was sectioned into ethics (including political theory) and logic (as the prerequisite for the study of both speculative and practical philosophy); in other words, first logic, then philosophy. Albert's methodology, as explained in the first section of his Physica (1987:I:1), is relatively straightforward and applies to the bulk of his output. His objective was to present Aristotle's texts as accessible as possible, as a result of which both the above double-index philosophical disciplines and Aristotle as 'The Philosopher' could be presented. The main themes and fundamental motifs in each of the Aristotelian texts are surveyed, explained by extensive footnotes and sidenotes, and illustrated with examples. Aristotle is thus to a large extent paraphrased, keeping the order and index of the original texts per Latin translation intact, albeit with a reformulation of essential concepts and the simple purpose of legitimising pagan philosophy for use in scholastic discourse. This forthright method of illuminating Aristotle's key concepts enabled a second element in Albert's commentaries, namely the employment of extensive excursions (indeed called excursus, which soon in high scholasticism ${ }^{2}$ became the standard reference for an extensive clarification), consisting of the identification of philosophical problems in the relevant texts, which are then addressed via the available perspectives of philosophers succeeding Augustine (354-430) and Boethius (480-524). This applies in particular where Albert was convinced that Aristotle's argument on a particular issue is

\footnotetext{
2.The author's suggestion for the internal periodisation of Medieval philosophy The author's suggestion for the internal periodisation of Medieval philosophy
comprises the following six-part scheme (for extensive argumentation, see Beukes 2020a:I:6-11): (1) The post-Roman period (5th to 7th centuries [410 \{Alaric I and the first successful barbaric invasion of Rome\} to 668 \{d. Constans II\}], with Augustine [354-430] and Boethius [480-524] as the leading philosophical exponents); (2) The Carolingian period (8th and 9th centuries [742 $\{\mathrm{b}$. Charles I\} to 877 \{d. Eriugena\}] with Alcuin [730-804] and Eriugena [815-877] as the leading Latin-West exponents of the Carolingian Renaissance, vis-à-vis the rise of Arabic philosophy in Baghdad and Andalusia Spain); (3) The post-Carolingian period (9th to 11th centuries [877 \{d. Eriugena\} to 1088 \{onset of the crusades and the rise of the first universities\}], \{d. Eriugelm [1033-1109] and Abelard [1079-1142] as the most influential amongst with Anselm [1033-110 ] and Abelard [1079-1142] as the most influential amongs the Latin-West thinkers who eventually profited from the rehabilitation of antiquity in the Carolingian Renaissance); (4) The early-scholastic period (12th to 13th centuries [1088 ffounding of the University of Bologna, the first European university to 1225 [b. Aquinas\}); and (5) The high-scholastic period (13th to 14th centuries [1225 \{b. Aquinas\} to 1349 \{d. Ockham\}, with Aquinas, Duns Scotus and Ockham as the most influential amongst the high-scholastics]); (6) The post-scholastic period (14th to 15 th centuries [1349 \{d. Ockham\} to 1464 \{d. Cusa\}]).
} 
incomplete and required substantial expansion. An excursus typically extended the relevant Aristotelian sections by initially arguing why an omission, intended or not, by Aristotle should be recognised as a problem, followed by suggestions aiming to address its correction.

This method to 'supplement' and 'improve' the Aristotelian corpus is at first blush simple and unassuming. However, Albert had to know the Aristotelian corpus extremely well to identify and expand the presumed omissions and bring the expanded text in dialogue with an array of Medieval thinkers, from Boethius in the 6th century to Albert's contemporaries. Albert's erudition is best illustrated by the extensiveness of the sources he employed to supplement Aristotle. This includes the whole spectrum of patristic literature (precisely in order to theologically legitimise Aristotle's theories) and literally every Arabic, Hebrew and Greek source text (in Latin translation) available to him, with repeated references to Heraclitus, Plato, Ptolemy, Galen, Vitrivius, Cicero and Boethius, as well as prominent Arabic thinkers such as Ibn Sina (Avicenna), Ibn Rushd (Averroes), Algazali and Alfarabi (cf. Beukes 2018c:1-3, 2018d:1-4). Albert's 40 volumes of philosophical commentary were the result of this minimalist methodology, his extraordinary erudition and the inheritances of his Medieval predecessors, on grounds of which Albert can be labelled the initiator of 'high scholasticism' - this 'reappraising' method would indeed become one of the essential features of the high scholasticism of the later Middle Ages, as in the work of Aquinas. The difference between Aquinas and by far the majority of high scholastics is that few of them possessed Albert's erudition. Aquinas was not only Albert's equal in this regard, but in fact surpassed Albert's 'greatness' by his ability to synthetically transcend his sources and not only commenting on them, however extensive. It is in this sense understandable that Aquinas was most often held in higher regard in Medieval reception history. Yet, it was Albert who was the first to bring Aristotle to the fore in the West in terms of the whole extant corpus in Latin translation - and made it impossible for his successors, however critical of Aristotelianism many of them were, to bypass Aristotle both in philosophy and theology. Aristotle was for Albert the one philosopher, next to Plato, which had to be studied thoroughly in order to engage any of the two disciplines in its Medieval presentation. Aristotle is therefore described (Albert 1968:I:1) as praeclarus philosophus, the most distinguished philosopher, and archidoctor philosophiae (1980:I:1), the major teacher of philosophy. The reception of Aristotle in high scholasticism would have been wholly different and impoverished without Albert's expositions. This is confirmed in the works of each of his Dominican successors in Cologne, as in the case of Berthold of Moosburg as well.

Albertism was thus institutionalised initially at the studium in the 1240s and later at the University of Cologne from the 1380s onwards. Unsurprisingly, the city of Cologne developed as a Dominican fortress in the light of both Albertism and Thomism being protected by its discursive contours - in which reinterpretations of Neoplatonism played a significant part. This is precisely the reason why the intellectual history of Cologne is still studied with main reference to its Albertist and Thomist perspectives, and on the basis of which that history can in this article be referred to as the 'Cologne tradition' of the later Middle Ages. For example, two eminent 20th-century historians, Gabriel Löhr and Martin Grabmann, focused in their chronicles of Cologne's academic history exclusively on the Dominican presence in and from Cologne from the second half of the 13th century onwards (Courtenay 1989:245). When later Dominican contributions, such as those of Ulrich, Dietrich, Berthold, Heymeric and Denys, are juxtaposed with Albert's and Aquinas' legacies, this unique Western European tradition is significantly expanded and enriched.

It was against the backdrop of Albertism and Thomism inevitable that Cologne would become the focal point of the Dominican crisis of the 1340s, brought about by the condemnation of 18 propositions (17 of which as 'heresy' and 11 as 'possible heresy') in the teachings of the early-14th century Dominican stalwart, (Meister) Eckhart von Hochheim (ca. 1260-1328), by pope John XXII (Jacques D'Euse, 1244-1334, pope 1316-1334) per papal bull In agro dominico, dated 17 March 1329 (Beukes 2020a:II:969-981). Eckhart's condemnation led to intense uncertainty and substantial disarray in the Dominican order for at least the following two decades. The resulting Dominican crisis of the mid-14th century, in German often referred to as Die Probleme der nacheckartschen Zeit (Sturlese 2007:3), effectively paralysed the order and had to be addressed rigorously from within the order itself. Berthold's primary text was composed during these two uncertain decades in the 1340s and 1350s, employing an unconventional strategy. Instead of predictably approaching the problem in the standardised Cologne-Dominican way of taking Albertism or Thomism as his premise, Berthold opted ${ }^{3}$ to reappraise the inheritance of one of the last philosophers of antiquity, the Neoplatonist Proclus Lycaeus (412-485), in an attempt to essentially reorientate the Dominicans in terms of what Berthold considered to be the order's most fundamental idea-historical (apart from Aristotelianism, obviously) source, namely Neoplatonism. Idiosyncratic as his rehabilitating programme was at once perceived to be, Berthold's reinterpretation and affirmation of the basic tenets of Proclian Neoplatonism were validated several decades later in the Neoplatonic reception of one the most prolific authors of the Middle Ages, Denys de Leeuwis, from the Carthusians' monastery in Roermond in the Netherlands. Yet, Berthold's reappraisal of Neoplatonism should be contextualised in terms of his most direct influence, apart from Albertism, in the work of his Cologne predecessor, Ulrich of Strasbourg.

\section{The impact of Ulrich of Strasbourg (ca. 1220-1277) on the Cologne tradition}

Ulrich was a fellow student of Aquinas, lecturer in theology both in Strasbourg and the Cologne studium, and eventually elected as prior of the German Dominicans in the province

3.See Ansulewicz (2019:1-14); Führer and Gersh (2014:305-317); Gersh (1986:701-704, 2001:493-503, 2002:3-30, 2014:31-74, 2019:1-16); Iremadze (1986:701-704, 2001:493-503, 2002:3-30, 2014:31-74, 2019:1-16); Iremadze
(2004); King (2018:184-199); Milem (2006:215-216); Palazzo (2019:1-11); Sannino (2000:243-258); Sturlese (2007:137-154) and Zavaterro (2011a:163-165). 
Teutonia. His most important work was Summa de Bono (or simply the Bono; cf. Strasbourg 1955:293-307), an extensive philosophical-theological summa, written between 1262 and 1272. In spite of being regarded in the dated reception as a mere commentator of Albert's works, the specialist research ${ }^{4}$ over the past two decades has succeeded in profiling Ulrich as an independent thinker within the broader framework of the Medieval history of ideas. The available research importantly indicates that Ulrich incorporated Albert's most central philosophical teachings, including his theory of the divine intellect (infra), effectively within the theological discourse of the 13th century. This integration of Albert's philosophical works into theological discourse indeed signifies Ulrich's attempt to establish a concordance of philosophy and theology as his primary goal.

The Bono was widely circulated, resulting in two reactions. On the one hand, a speculative philosophical reaction to Ulrich's work established itself, with reference to a number of 14th-century Dominicans from the studium in Cologne, notably Dietrich and Berthold, whilst on the other hand, an ethical and pastoral reception of the work became evident in the writings of Dominicans who were more theologically inclined, like Johannes Freiburg, one of Ulrich's students in Strasbourg. Ulrich unfortunately received too late permission of the order to commence with advanced studies in theology at the University of Paris. He died before he could be promoted to magister in theology, as a result of which the German Dominicans passed a golden opportunity to have a German take up the chair in Paris reserved for non-Parisians.

As the title indicates, the Bono comprises themes associated with the absolute good (or 'the Good') indexed in the summa as six books: (1) A Theological Introduction to the Good, (2) The Essence of the Good, (3) The Divine Persons, (4) The First Person and Creation, (5) The Second Person and the Incarnation and (6) The Third Person, Grace and the Virtues. Although Ulrich indicated in the Preface that seventh (on the sacraments) and eighth (on aesthetics) books were written, there are no indications in any codex of the existence or survival of these two works (although the sixth book concludes without the summary normally found at the end of the last volume of a scholastic text, indicating that at least a seventh volume was probably circulated before the end of the 13th century). The critical edition of the Bono shows that Ulrich was deemed a respectable theologian in his own time and that the work was received as an original contribution within the scholastic landscape of the second half of the 13th century. Different from Albert and Aquinas, Ulrich opted not to use the established scholastic method of question and answer with pro and contra arguments. He instead presented the work expressedly as a reference work intended for educational purposes and use in monastery libraries. Albert's textual legacy is evident in the work, especially with regard to his Metaphysica, De Causis et proccesu universitatis and De intellectu and had not been re-edited since. et intelligibili, on grounds of which Ulrich was often depicted as 'Albert's favourite' and the 'co-founder of Rhine theology' (Palazzo 2004a:1-6).

These otherwise positive indications are, however, not a correct portrayal of the independence of Ulrich's thought and are at risk of reducing him to a mere associate and commentator of Albert's legacy. The most recent research (Palazzo 2019:13) draws Ulrich out of the shadows of his master and indicates that Ulrich did not hesitate to differ from Albert on crucial points. For instance, he did not share Albert's (rather typical early scholastic [cf. Beukes 2020a:I:393-398]) methodological preference to consider philosophy and theology as unique and different sciences, which should be distinguished firmly from each other. In fact, Ulrich argued that philosophy and theology share essentially the same methods and objects of study, although the two disciplines maintain these with a unique vocabulary. It is in this sense that Ulrich advocated for a concordance of philosophy and theology, by which he meant that speculative philosophy should provide the basis and (hermeneutical, in modern terms) presumptions for theological research. This concordance predictably manifested itself to minimise the differences between PlatonicAugustinian and Aristotelian thinkers. In an untypical move for a Dominican, Ulrich nevertheless qualified that he considers Aristotelian philosophy as subordinated to Platonism, because the theoretical domain of Aristotelianism is restricted to the empirical-scientific exploration of reality, whilst Platonism in his view has a broader scope in the applicability for the search of knowledge of God and the attributes of God. He thus reworked the well-commented passage of Albert himself (in Metaphysica XI.3.7) where the 'Aristotelian way' is contrasted with the 'Platonic way', to substantiate his preference for the latter. Ulrich argues that the 'two ways' are in many aspects the same way, but only as long as Aristotle is treated with sober judgement, acknowledging the contributions of the Aristotelian thinkers, from Pseudo-Dionysius (Beukes 2018a:1-3) through the Arabic falsafa (Beukes 2018c:502-505, 2018d:565-568) up to the introduction of the extant Aristotelian corpus in Latin (from the Arabic translations of the Greek texts) in the first two decades of the 13th century.

One of the most striking features of the Bono is Ulrich's development of Albert's theory of the (divine) intellect (Ansulewicz 2019:2-4). Albert constructed a philosophical-anthropological premise from the first chapter of Aristotle's Metaphysica, namely that the human being is a link or connective agent between God and the world (homo nexus Dei et mundi). The human being is considered such because the human subject carries a mundane earthiness in itself and represents a fateful and often disastrous association with the world, yet possesses something that transcends it mundaneness, namely the intellect. The human intellect is in this sense divine because God is divine. Based on this soul-correspondence or unum animae between God and human, God may be reflected by the human subject, in all the latter's frailty. This innate human faculty, often depicted in the philosophical tradition as intellectus agens or the active 
intellect (and in the theological tradition imago Dei, of course), enables the human subject to an intellectual unification with God. Whilst this postulation undoubtedly was one the most directly philosophical elements in Albert's oeuvre, Ulrich situated the intellect without reserve within a theological framework. He departs anthropologically from this same presumption regarding the intellect Albert employed in the first chapter of Metaphysica, but soon moves to explain it in terms of a Neoplatonic emanation (see infra) where the soul ascends or returns to God (Bono II.4.1.4; II.3.5.5; IV.1.2.7). Initially, Ulrich stresses the natural characteristics of the active intellect, which is thus the principle of the pre-eminence of the soul (with all its faculties, whether will, intellect or memory) midst mundane considerations, operating independently of grace and revelation. The process that leads the human subject to a contemplative sense for beauty and perfection is equally mundane. However, the active intellect ascends in sequential phases of knowledge, from the thorough commonplace to becoming divine intellect, whilst the union between active intellect and divine intellect is realised in a contemplative life before God and the world of substances. The beatitudo or blessedness of human existence is established in this cognitive union with God.

Whereas the theory of an intellectual knowledge of God was for Albert only applicable in a strict speculative and philosophical realm, Ulrich designated a theological validity to it: Knowledge through speculative reason and knowledge through faith are eventually the same knowledge. His insistence on a contemplative beatitudo played a progressively important role in the historical development of the German mystical tradition, especially in the case of the condemned Eckhart himself. As mentioned, Ulrich argued for a concordance of philosophy and theology and, therefore, effectively for a symbiosis of philosophy and mystical knowledge. In addition, he applied this Neoplatonic version of the divine intellect to ethics. The active intellect as a divine property present in the human subject, independent of and liberated from the material nature of the subject in the world, enables the subject to control over its choices. Hereby Ulrich opened an avenue for the extensive development of the virtues. Just as the subject through the action of knowledge is enabled to truly know God, independent of grace and revelation, thus perfecting the intellect, the subject is able to develop and bring to perfection the subject's own moral excellence - as indeed a kind of 'divine merit through virtue'. The subject can excel in this regard without any intervention by a principle or event external to the soul including God and fate. The subject brings to perfection that which is already an innate possibility, by the action of reason, which determines all moral actions. Berthold would rework these notions with singular originality.

\section{Berthold of Moosburg (ca. 1300-1361): A case study from the Cologne tradition}

Biographical information on Berthold of Moosburg is extremely scarce. He is depicted in the historical records of the Dominican order simply as a '14th-century Dominican friar' (Sannino 2000:244; cf. Löhr 1946:42). As his work was brought into modern scholastic scholarship only in the first decade of the 20th century, after the discovery of a crucial manuscript of his Expositio super Elementationem theologicam Procli in the Vatican Library in 1900 (Klibansky 1928-9:1-41; cf. Mynors 1963:223-224), the only facts about Berthold's life not in dispute are that he visited Balliol College at the University of Oxford at the young age of 16, was lecturing at the Dominican priory in Regensburg by 1327, was mentioned as the executor of testaments and estates in Cologne on three different occasions (in 1335, 1343 en 1361) and that he represented the Dominicans in 1348 at the Natio Bavariae in Nuremberg (Sannino 2000:244). This severely restricted biography unfortunately led to significant confusion over Berthold's identity, aggravated by the use of several and seemingly arbitrary proper names: 'Berchtold' or 'Berealdus' in the Balliol codex (Mynors 1963:223-224), 'Bartholomeus' and 'Berthold' in the Vatican manuscript and 'Bercaldus' in the catalogue of Oxford manuscripts (Sannino 2000:244 [fns.11-17]).

After being called up (at long last) from Regensburg to the Dominican studium in Cologne in Cologne in 1355, Berthold (Moosburg 1984-2007) presented the Expositio super Elementationem theologicam Procli (henceforth Expositio), a

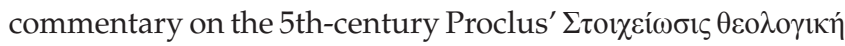
(Stoicheiosis Theologikae; Elements of Theology) as a tactical escape route from the impasse left by the Dominican crisis. His main objective was to set up a Dominican defence (not only of Eckhart, but of several other Dominicans, who were at that stage associated with 'mysticism' [as in opposition to 'scholasticism']), not by predictably reappraising Aristotle in the scholastic footsteps of Albert and Aquinas, but by affording this massive nine-volume commentary on Proclus' version of Neoplatonism. The Expositio, written between 1340 and 1361, can justifiably be called one of the most outstanding contributions on Neoplatonism from the overall millennium-long epoch of the Middle Ages (cf. Gersh 2001:494). By presenting the Expositio, Berthold also became the only author from the Medieval Latin West ever to write a specialised commentary on Proclus as such. The work was based on a late 13th-century Latin translation of the Greek text by another Dominican, Willem van Moerbeke (Führer \& Gersh 2014:299; cf. Boese 1985:1, per Sannino 2000:243 [fn.1]). Almost three decades after the finding of the Vatican manuscript in 1900, an alternative manuscript was discovered at Balliol College at Oxford (Klibansky 1928-9:1-2). Editing of the text (in Corpus Philosophorum Teutonicorum Medii Aevi VI, 1-7) commenced in 1974 and was published in successive stages under editorship of several eminent Medieval specialists, including M.R. Pagnoni-Sturlese, L. Sturlese, B. Mojsich, B. Faes de Mottoni, I. Zavaterro, I. Tautz and U.R. Jeck. The final printed copy of the nine volumes will comprise around 3000 pages (Sannino 2000:243 [fn. 4]). However, to put Berthold's rehabilitation of the Neoplatonic-Proclian inheritance in perspective, we need to take a step back to Proclus' own Neoplatonist predecessors, Plotinus and Porphyry. 


\section{'Excursus': The Neoplatonic inheritance in Medieval philosophy}

The Neoplatonic legacies of Plotinus and Porphyry were a focal point in virtually all of the mystical thinkers of the Middle Ages, from the Arabic-Jewish trajectories in the post-Roman and Carolingian periods (Beukes 2018c:1-3, 2018d:1-4), the Syrians Pseudo-Dionysius (Beukes 2018a:2-4) and Maximus Confessor (Beukes 2020a:I:105-110), and then, from Europe, John Scotus Eriugena (Beukes 2020a:I:123-134), to later mystical exponents such as Richard of Saint-Victor (Beukes 2020c:6-7), Mechtild von Magdeburg (Beukes 2019:3-4), Marguerite Porete (Beukes 2020b:3-4) and Eckhart himself, up to Berthold in the 14th century, with a last Medieval annotation before the Renaissance by the 15thcentury beacon of 'post-scholastic' philosophy, Nicholas of Cusa (Beukes 2018b:1-4). 'Neoplatonism' in general refers to a philosophical system constructed by the Greek author Plotinus (204-270) and the revision of that system by Plotinus' successors, in particular Plotinus' scribe Porphyry (ca.234-ca.305), as well as Amelius (fl. 259, who left an annotating commentary of 100 volumes on Plotinus' thought [O'Meara 1995:1]), Eustochius (fl. 260), Serapionus (fl. 260), Castricius Firmus (fl. 250), Iamblichus (ca.245-ca.325), as well as the later Macrobius (fl. 400), Martianus Capella (360-428) and Marius Victorinus (fl. 355; Gersh 1986:421-729). Plotinus was born in Egypt and received his education in Alexandria (Armstrong 1962:11-15; O’Meara 1995:1-10; cf. Gerson 1994:xii-xiv). Somewhat later, from around 244, during a tempestuous period throughout the whole Roman Empire, he lectured philosophy in Rome and established a small society, which focused on a critical and original reappraisal of Plato's texts and other inheritances from the Old and Middle $^{5}$ Academy. Porphyry was responsible for the editing

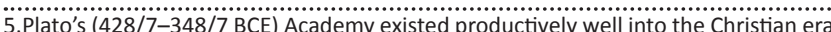
but as a school of philosophy it underwent several theoretical transformations over the as a school of philosophy it underwent several theoretical transformations ove the course of the four centuries (Dillon 1990:51-59). Confronted by the authentic philosophical claims of the Stoics, established by Zeno (495-430 BCE), and the Epicureans, established by Epicurus (341-270 BCE), the Academy in the generation directly after Plato withdrew into scepticism and philosophical agnosticism (Tarran 2011:XX23-37). The Academy in this second-generation period after Plato is known as the 'Middle Academy' or 'Second Academy'. The philosophical disposition of the Middle Academy was apologetic, in the sense that it over the course of 150 years focused on a defence of Plato's philosophy against, on the one hand, Aristotle and the Lyceum's philosophical attack on the central tenets of Plato's philosophy, and on the other hand, against emerging philosophical systems, precisely as in the case of Stoicism and Epicureanism. This period of apologetic withdrawal was eventually transformed into a new critical period by Carneades of Cyrene (214-129 BCE), who restructured the Middle Academy into the 'New Academy'. Characteristic of the New Academy was its philosophical insistence on 'probability' both in theory and in praxis. Although initially an underrated theoretical position, it gained popularity praxis. Although initially an underrated theoretical position, it gained popularity with the entrance of the celebrated Roman author Cicero (106-43 BCE) to its midst. Cicero's philosophical erudition and influence was of course restricted when measured against his formidable literary output and corpus, but his informa relation with the theoretical premises of the New Academy did provide impetus to the Academy's survival deep into the early-Christian era. The Academy had at this point little more than a historical connection with Plato: At this stage there was such an overall susceptibility for new ideas that the 'authentic Plato' was weighed down by attempts to find similarities between Plato and Aristotle and even to achieve a symbiosis of their theoretical positions, radically different as they were. In addition, impulses from stoicism and epicureanism, as well as a revived Pythagoreanism, led to the development of a hybrid transitional philosophy which was labelled 'Middle Platonism'. Middle Platonism, precisely as a hybrid philosophy, included a vast array of thinkers, no longer only from Athens, but now from the other big centre, Alexandria, as well. As Middle Platonism is effectively a 'position in transition', its periodisation should be supple, but 80 BCE to 220 CE is regarded as an acceptable marker. Although foundational premises should be treated with caution in such hybrid context, it is possible to indicate some recurring themes in Middle $\mathrm{Pl}$ such The notion of nous or 'mind' takes central stand in Middle Platonism (Dillon 1996:6) The notion of nous or 'mind' takes central stand in Middle Platonism (Dillon 1996:6) was presented as a combination of the ideas of the Good in Plato and the unmoved mover in Aristotle. Middle Platonism did not shy away from reflecting on the mover in Aristotle. Middle Platonism did not shy away from reflecting on the
Platonic Forms as thinkable by the mind, as well as attributing a pertinent, defined status to the Forms, which of course was absent in the classic Platonic version. The and indexing of Plotinus' writings, which eventually manifested in six volumes comprising of nine essays each, titled the 'Evveá $\delta \varepsilon \varsigma$ (Enneades; literally the 'Nines'). Although Porphyry knew the development and chronology of the 54 texts very well, he opted to organise them thematically. The first three Enneades focus on the immanent: Enneades I centres on the human and ethics, Enneades II focuses on physical reality and Enneades III focuses on philosophical problems regarding the world, such as fate, foreknowledge, time and eternity. Enneades $I V$ is a treatise on the soul, Enneades $V$ is a treatise on the mind and Enneades $V I$ is a treatise on the being and the 'One'. Plotinus' thought is manifested in two principal themes: source and return, 'from where' to 'whereto' (or 'emanation'). The Enneades present a description of the descending source of all things from unity and perfection, back to an ascending plurality. The characteristic Middle-Platonic attempt to describe reality in terms of a transcendent principle is hereby drawn to its logical consequences. The transcendent nous or mind that was so central in Middle Platonism is typified by Plotinus as insufficient because thought and the object of thought are still distinguished from each other and, therefore, unable to posit a final transcendent concept of unity. Plotinus, therefore, presents a principle that for him represents the highest form of singularity, simplicity and indivisibility, namely the One. The simplicity, indivisibility and pure transcendence of the One surpasses any categorisation, which means that the One under no circumstance can be a predicative subject; in other words, the One cannot be described or understood by means of any one or more of Aristotle's 10 categories. In addition, a teaching that goes back to Parmenides and presents through Plato's entire oeuvre is implemented: 'To be, is to be comprehensible'. What is, is understandable. What cannot be understood, 'is-not', in other words, beyond being. Therefore, Plotinus' reflections on the One focus inevitably on the consequences or implications of the One, whilst the One's nature in itself is not engaged. That does not imply that Plotinus' concept of the One has no positive content; his concept of reality centres around the productive quality of the Good, of which the One is the absolute representation. Therefore, the One (to hen) and the Good (to agathon) are employed as conceptually interchangeable (cf. O’Meara 1995:8).

\footnotetext{
transcendence of the mind, indebted to the Pythagoras-influence, and the mind's relation to the physical world are accentuated via intermediary concepts such as Logos, which in the Second Testament of the Christian Bible (virtually all the texts of which were written during the apex of Middle Platonism) is a central concept (cf. Tarrant 2011:XII197-204). For Medieval thinkers the importance of Middle Platonism established itself on at least three levels. Firstly, Middle Platonism provided the most essential concepts from Greek philosophy (although distilled by the demands of its hybrid position) for the first two centuries of Christendom's the demands of its hybrid position) for the first two centuries of Christendom's whether it was directly absorbed or (more probable) indirectly incorporated by whether it was directly absorbed or (more probable) indirectly incorporated by means of Hellenistic influences on Judaism, is evident in, for example, the Gospel of
John. At the time it already left its mark on the thought of the historian Philo of Alexandria (20 BCE $-40 \mathrm{CE}$ ), was already deeply embedded in Jewish theology (Dillon 1990:XI1-8) and exerted a significant influence on early Christian theology (Haren 1985:30), as visible in the works of Clement of Alexandria (ca. 150-215) and Origen (184-254). Secondly, theoretical positions associated with Middle Platonism contributed directly to the sources of Medieval philosophy: For example, Calcidius' influential translation of Plato's Timaeus from Greek to Latin (which would be the only extensive text of Plato available in the Latin West for the next 800 years; Gersh 1986:421-492) and his commentary on the text, are much more indebted to Middle Platonism than to any other developments at the time, although it was probably written in the fourth cor probably written in the fourth century when Middle Platonism already had to make room for Neoplatonism (Wagner 2008:275-288). Thirdly, Middle Platonism was precisely the crucial predecessor to Neoplatonism, which exerted an unprecedented influence on Christian theology in late patristics and early Medieval philosophy, as well as the way Aristotle was received and interpreted in the first decades of the 13th century,
as visible in the works of Albert, Aquinas and their successors such as Ulrich, as visible in the works
Dietrich and Berthold.
} 
Plotinus consequentially works with three hypostases: the One, the mind and the soul. From the One, a potentiality for being - the matter of intelligent life - is generated in descending order. The first descending being is mind, which replicates the simplicity and singularity of the One, but already is not further able to replicate the unity of the One. The mind directly causes everything that is comprehensible: all forms of reality, including the forms of individual being. The mind does not produce the forms by thinking the forms: the forms are already the nature of the mind, and by knowing the forms, the mind knows itself, in correspondence with the Aristotelian principle that thought and the object of thought are identical. Plotinus in this way retains the objectivity of the forms, whilst the forms are being incorporated within the system of descending generation or emanation. Just like mind was generated by the One, the mind in turn generates the principle of the soul (psuche). Clearly taken over from Plato's Timaeus, the soul is presented as the 'bridge' between the intellectual and sensory worlds. As a 'bridge', the universal soul consists of two dimensions. The first, higher dimension of the soul seeks comprehension of the mind in ascending way, whilst the second, lower dimension represents the principle of order in the material world (nature) and in terms of emanation reproduces the forms already present in the mind. The forms of corporeal things are the individual souls, which have the same double-sided character of the universal soul. In the descending emanation from the One, matter is the last and most remote limit of reality. Matter is the pure potentiality for formation but is also intrinsically empty: it is only when 'formed' by the soul that matter 'becomes'. Plotinus is, therefore, suspicious of matter because it is empty, and it also has a weakening effect on the soul. Matter, as the last form of being and thus the lowest emanation from the mind, obscures the true and authentic character of the soul. Liberation from material entanglement and cosmic ascension to the reunification with the mind is, therefore, the mind's highest aspiration.

In terms of Berthold's reappraisal of Neoplatonism from the later Middle Ages, it is important to stress that Porphyry was not a mere editor of his master's written work, although that was certainly his most significant service to Neoplatonism. Porphyry's own works were influential. His introduction (Isagoge) to Aristotle's Categoriae is a good example of the meticulous word-for-word style of commentary, which would define the scholastic method centuries later. In addition, Porphyry's interest in Aristotle would significantly influence Boethius' (ca. 477-524) later commentary with the same title. The Isagoge was in fact used in the Middle Ages as ' $\mathrm{n}$ standard commentary on the Organon and was indirectly responsible for the premises employed in early Medieval debates on the status of universals, notably in the works of William of Champeaux (Beukes 2020a:I:331-341) and Peter Abelard (Beukes 2020a:I:343-355). But even more significant, several of Porphyry's own texts (of which the majority were lost) were available to Augustine (354-430). Augustine accordingly rather used Porphyry than Plotinus to disseminate Neoplatonism (Armstrong 1962:45-48). Porphyry's own work also represents an intentional effort to simplify the mystical and often ambivalent qualities of Plotinus' thought, for example, he tended to reduce the distinction between the mind and the dimensions of the soul and rather stressed the dualism of soul and matter - in that sense, he was explicitly Middle-Platonic. He was also engaged in polemics during the peak of Neoplatonism to a far greater extent than Plotinus himself. It is not certain whether Porphyry was informed on dogmatic developments in early Christianity, although he was opposed to the kind of gnosticism with which Christian theology was associated with at the time; indeed, he was committed to the rehabilitation of pagan religion, which was a dominant feature of the last phases of Neoplatonism.

\section{The aim of Expositio super Elementationem theologicam Procli}

With the Expositio, Berthold thus attempted to take the Dominicans back to their - in his opinion - authentic roots. Whereas the Franciscans of the later Middle Ages employed Augustine to a significant extent as their main philosophical source, the Dominicans historically prioritised Plotinus and Porphyry, as well as their successor Pseudo-Dionysius, whilst both mendicant orders fully optimised the availability of Aristotle's extant texts in Latin translation at the beginning of the 13th century. Berthold presented Albert as the crucial transitional figure between the Neoplatonic inheritance and the 14th century Dominicans' reception, by arguing that Albertism created an autonomous and homogeneous intellectual identity, of which the roots were situated in antiquity - and precisely Proclus, according to his reading, was the most authentic exponent of this particular tradition in antiquity.

Berthold actualises Proclus as a homo divinus (Sturlese 2007:148); or after his full latinised name, Proclus Lycaeus, as a

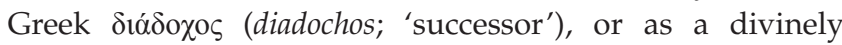
inspired leader in the tradition of the successors of Alexander the Great - a leader able to comprehend the divine attributes in an instant, as it is present in the totality of the life-world system. According to Berthold, a homo divinus such as Proclus can ascend to God in the emanational sense of the word on the basis of reason alone. In a similar vein, the scholastic philosopher who studies and incorporates Proclian emanation, is also able to know and contemplate God in an unmediated sense; this is possible with relation to the presence of the 'higher man' (i.e. the human subject on the Proclian trail) in the psychological faculty of the divine itself, which Berthold articulates in a Platonic sense as the 'One of the soul' (unum animae). His uncontroversial reception depicts Proclus as a thematic successor of both Plotinus and Porphyry, but stresses Proclus' own idiosyncratic implementation of the work of the aforementioned Syrian Iamblichus (245-325, Pseudo-Dionysius' direct philosophical predecessor). The influence of Iamblichus caused Proclus to work with a more extensive universum and more mathematical divisions (211 theoretical postulations) than Plotinus' and Porphyry's Enneades. 'Where there are numbers, beauty is present', according to Proclus. 
The main characteristic Neoplatonic strand is retained in Berthold's reading of Proclus. The One is maintained as a single principle that from the highest form represents simplicity and indivisibility. The question is how Berthold contributed to the Cologne tradition (via Albert and his students Aquinas and Ulrich), within the context of the crisis of Eckhart's condemnation in 1329, with this Proclus-reception in Cologne around 1355. It must be noted at once that Berthold in the long term did not succeed in expanding the Cologne tradition, because of resistance from his own order to employ a Neoplatonist (rather than an Aristotelian) tactic to diffuse the crisis. Eventually Berthold would only be re-engaged again towards the end of the Middle Ages, literally by the time of the transition to the Renaissance, by the 'gatekeeper of modernity', Nicholas of Cusa (Beukes 2018b:2-4). The lukewarm reception of the Expositio in Berthold's own time should nevertheless not diminish the exquisiteness of the work - as well as that Berthold indeed presented himself as an original exponent of the Cologne tradition.

\section{Berthold's Proclus-reception and discursive intersection with Meister Dietrich}

Berthold's Proclus-reception was thus strategic from the outset. By a reinterpretation and representation of Neoplatonic and specifically Proclian teachings, he attempted to critically resist the paralysing effect of the condemnation of Eckhart. Although the Expositio is Berthold's only extant work, it becomes clear that he not only readdressed Proclus' Elements of Theology but also Proclus' later works, namely his commentary on Plato's Parmenides and the Opuscula Platonica. Again it was a tactical choice, knowing that these two works would prove to be particularly significant within an explosive context where not only theology but anthropology and ethics would also play a significant role. Berthold indicates in the Preface of the Expositio that he commented on these two texts of Plato thoroughly, before he started working on the nine volumes (more than 2000 pages in the earliest printed editions), which eventually comprised the Expositio. Unfortunately, those two commentaries were lost, and the research is thus dependent on Berthold's implementation thereof in the Expositio to deduce its content.

Berthold argues that it is possible for the rational subject to 'ascend to' or 'return to' God on the basis of his application of the 211 Proclian statements, which he thoroughly analyses in the first volumes of the Expositio. By 'ascending to' or 'returning to' God, the 'Proclian man' is enabled to contemplate the 'divine, exclusively divine' - that is the highest Good, the Bono, after Ulrich. The human subject, still earthbound, is enabled in the here and now to accomplish the eternal perfection this subject is destined for and to return in reditus to God - being not only a subject under the grace of God, but indeed a 'divine man'. Berthold finds the most essential objective of Proclus' work in a systematic ascension, which departs from the real frailty of the world (which nevertheless is already divine, in the sense that the One participates in it) and is at last (again) eventualised in the One. He states explicitly that this Proclian, contemplative subject - to which he also refers as 'philosophical man' understands the divine realities based on a unique cognitive principle, which makes possible the emanational ascension to the One. This unique principle is unum animae (after Plato's Opuscula Platonica), which has absolute authority and priority over any other human faculty.

Berthold maintains that Proclian henology (the 'teachings on the One') should be prioritised above Aristotelian ontology because it is not restricted by a dimension of being - which indeed is the case in Aristotelian metaphysics. In fact, Proclus (like Plato and the pre-Socratics) presented a supra-intellectual knowledge, which could only be comprehended by the unum animae, as a knowledge that understands the first two principles of all principles spontaneously, namely the highest Being (super Entia) and the highest Good (Bono). Berthold focuses with extensive analyses on these, in his opinion, restrictions of Aristotelian metaphysics. This metaphysics is restricted because its metaphysical domain of inquiry is itself restricted to the realm of being and not able to set the human subject in principle in the presence of a divine, supra-being reality; a reality superior to the intellect, where the human subject is nevertheless enabled to know the One. That is why the unum animae is for Berthold the deepest and most profound cause for the superiority of Platonism over any other philosophical system - even above Neoplatonism, which itself reworked the Platonic principles with authority. Proclus is, therefore, according to Berthold, on the basis of the unum animae Proclus himself possessed, pure homo divinus - and the most important of all pagan thinkers who spontaneously grasped the invisible divine qualities (invisibilia Dei) to such an extent that he was able to ascend to the One by natural reason alone. This depiction of Proclus, as pure homo divinus, is then connected with other elements of Pre-Socratic teachings, according to which concepts such as microcosmos, macrocosmos and homo divinus are on Albert's trail coherently presented as the link between God and world (homo nexus Dei et mundi), as the connection point or nexus between two realities, the material and the divine.

With his Proclus-reception thus grounded, Berthold moves to situate Proclus explicitly within the Dominican crisis. This is done with reference to Berthold's own embeddedness in Albertism and his conviction that Albert was able to create an autonomous intellectual identity for the Dominicans, of which Neoplatonic elements played a significant part. He refers in particular to Albert's theory of fluxus (also incorporated by Ulrich) in his explanation of the initial causal emanation of the First Intelligence or Principle (light), which in descending movement 'flushes' through everything and starts to generate a plurality of beings - these beings are identical to the First Intelligence in terms of essence, but non-identical in terms of diversity and plurality, given the oneness of the One. Berthold also reworks Albert's theory of the divine man, as expressed in his theory of the divine intellect, as discussed supra (cf. Ansulewicz 2019:2); it was indicated that Albert constructed a philosophical-anthropological premise from the first chapter of Aristotle's Metaphysica, namely that the human subject is the link or connective agent between God 
and world, or homo nexus Dei et mundi. Based on this soulcorrespondence or unum animae between God and human, God may be reflected by the human, in all human fragility. This innate human faculty, often depicted in the philosophical tradition as intellectus agens or the active intellect, enables the human subject to an intellectual union with God. Berthold, however, extends Albert's reworked synthesis, by repeatedly associating unum animae with Augustine's abditum mentis ('abyss of the mind') and Pseudo-Dionysius' unitio ('unification' [of God and the human subject]; King 2018:184-185). As Albert did not go into it himself, Berthold then employs, apart from his incorporation of Ulrich's thought, the work of a third Dominican predecessor to illustrate (in his conviction) the relation between Neoplatonism and the Dominican tradition, namely Meister Dietrich of Freiberg's (ca.1250-ca.1310) theory of essential causality (Ansulewicz 2019:1; for the Proclian influence on Dietrich himself, cf. Führer \& Gersh 2014:299-302).

Dietrich's ${ }^{6}$ metaphysics insists on the equality or real identification of the essence and existence of all beings, with the Thomist distinction between essence and existence thereby repudiated. Therefore, Dietrich refuses to distinguish God from created beings by the postulation of a theoretical universal hylomorphism, on the basis of which all created beings, including the 'intelligences' or 'celestial beings', possess a basic form of materiality. He argues that the intelligences possess no form of materiality. But how does he then distinguish between uncreated being and created being, and the various forms of created being? For Dietrich, and herein Berthold follows him closely, the answer lies in the essential relations of these entities in a universitas of being; in other words, the place that a particular being occupies in the hierarchy of being, in terms of which the particular being is placed in an order to another being as either the cause or the effect of that other being. All beings are placed in descending order from God and in essential order from each other. That is also what Dietrich means by 'place'; he does not mean an incidental or contingent relation like 'left' or 'east' or a relation that can change without changing the essence of the being involved in the relation. Hierarchical placing is, therefore, fundamental for Dietrich. Of course, the easy answer to the question of God's distinction from the rest of the universum would be to simply postulate God as 'creator' - but for Dietrich it is far more subtle. That is why he is sensitive to keep the philosophical objective of his position close to the representation of God's emanational-creative nature in both Plotinic and Proclian Neoplatonism; God as the One indeed shows interior transfusio, an 'overflow of Godself to the bottom'. In other words, in the abundance of being, being becomes possible.

The whole of being is in this specific Neoplatonic sense created by God 'out of nothing'. But Dietrich is reluctant to

6. See Aertsen (1999:23-47): Birkenmajer (1922:70-90); Flasch (1972:182-206 1985:7-26); Führer (1992:1-22, 1999:69-88); Goris (1999:169-188); Jeck (1999:89-119); Kandler (1998:642-647); Kobusch (1987:46-67); Krebs (1906:5-6); Largier (1999:149-168); Maurer (1956:172-203) and Mojsisch (1987a:106-114, 1987b:95-105) simply (i.e. non-Neoplatonically) refer to God as 'creator out of nothing', because it is a proposition that allows for the possibility that God's being itself was created, albeit self-created. By placing creation in a hierarchy of being with reference to an emanational relation to the One, the dangers of pantheism are also bypassed, which had destructive consequences in the works of early Christian Neoplatonists such as John Scotus Eriugena (815-877; Beukes 2020a:I:123-133). God may well be 'in all things', but then specifically in the mode of an essential cause (per modum causae essentialis), which means that God and creatures do not share the same being. God's being is not created but creative - and this attribute is unique to God. This is another feature in Dietrich's thought that Berthold maintains, but again he goes further. No creature can create, because as a creature it only possesses non-creating being, which always is different from God's being (aliud esse). Some creatures may well possess the ability to produce, but production for both Dietrich and Berthold is something wholly other than divine creative ability. Creation is the bringing-into-being of being from the abundance of being, whilst production is a formal attribute of causality some creatures possess. However, some creatures' ability to produce and reproduce is fundamental in both thinkers' metaphysics of the intellect, precisely because the intellect in the hierarchical ordination of things flows immediately to (and of course from, initially) God and is in this sense a reflection of God's omnipotence; just as God is able to create totality emanational-descending, the intellect is able to reflect or reproduce this totality as ideas - including ideas regarding God self (Führer 1999:75-80).

Dietrich's late 13th-century version of the Neoplatonic hierarchy of being was thus reworked and revalidated by Berthold in the 14th century. By identifying the Neoplatonic One nuanced and metaphysically with the creator-God of high scholasticism, a dynamic element was added to the hierarchy of being, according to which God brings beings into existence from nothing (yet from the abundance of being), whilst 'marking' these beings with a similarity to God self. Berthold, in his discursive intersection with Dietrich, hereby provides a continuity notion of being. The similarity simultaneously provides a dynamic structure to the complete hierarchy of being whilst acting as an essential link between the intellect and the rest of the hierarchy; thus, as simultaneously a principle of being and an epistemological principle. However, the similarity to the complete hierarchy of being is not made possible by the intellect itself - in fact, the similarity forms part of the authentic nature of the intellect (cf. Führer 1999:69-74).

In his distinction between the plurality of beings that constitute the hierarchical universum, Berthold follows Plotinus (again, on Dietrich's trail), but with progressive focus on Proclus, Pseudo-Dionysius and Ibn Sina (Avicenna) in their corresponding emanation-divisions. Firstly, there is God as One, followed in descending order by the intelligences, then the souls and eventually the bodies. From God descends the first intelligence, then the second intelligence in (as the soul of) the first celestial sphere, down to the third intelligence 
as the soul of the second celestial sphere, up to the last intelligence and last sphere (the heavens). The whole universitas of being is hereby involved in a state of active descension of all creatures from God; followed at last by emanational reditus, the return or ascent of the descendants to the One. All things eventually return to God, except for God, who cannot return to God self. The relation between the intellect and the rest of Berthold's Neoplatonic universum is clearly an intimate one; the relation between what is or real being (ens reale) and what can be conceptualised or conceptualised being (ens conceptionale) is, therefore, a crucial consideration in the understanding of things, 'as they truly are'. The distinction between real being and conceptualised being is indeed the first division of being. In addition, conceptual being for Berthold does not only include the objects of the knowing act, but the knowing act itself. This knowing act is not a mere reception or reproduction of an object, which appears to the intellect from the outside, but is semi-creative, in the sense that the knowing act is simultaneously the act of understanding the object. This could be compared with the reproduction of living things in the sense that a new reality is established with the reproductive act, apart from the fact that the knowing act itself is reproductive in any case, in the sense that it provides a reflection of an external reality.

Berthold's reappraisal of Neoplatonic perspectives in his Proclus-commentary is extensive and original; it has been indicated supra that he focused on the development of a speculative synthesis of his Neoplatonic and Dominican sources in order to present his theory of homo divinus as the theoretical matrix of the German Dominican tradition. The four figures that are paramount for Berthold in his original synthesis of a homo nexus Dei et mundi are thus the antique Proclus and his Dominican predecessors, Albert, Ulrich and Dietrich. Berthold's unique contribution from the Cologne tradition was that his Expositio thus synthesised a late Medieval reappraisal of Neoplatonism with a unique reinterpretation of existing Dominican theories. By contextualising the teachings of his German Dominican predecessors in the vast idea-historical landscape of antique and Medieval Neoplatonism, he succeeded in credibly reconnecting the full Neoplatonic tradition - precisely with his accent on Proclus - with broad Albertism, indicating the consolidating ability of this tradition. The additional bonus to Berthold's project was that there now was, for the first time since Aquinas, a sustainable alternative provided for the robust Aristotelian-driven scholasticism in Paris and (although to a lesser extent) in Oxford.

Whilst the Expositio initially gained ground within the Dominican order - midst immediate accusations of 'idiosyncrasy' - on the strengths of the impressive extent and stylistic refinement of the work, the Expositio's influence diminished relatively quickly after Berthold's death in 1361, not least because of resistance from within the order itself. The 14th-century Dominican Thomists and followers of the 'Latin-scholastic' Eckhart (contra the followers who rather focused on the 'German-mystical' Eckhart) insisted on a purely Aristotelian-driven project from within the order, which supposedly would resonate and integrate Eckhart's condemnation within the broader scholastic landscape. Berthold's Expositio was thus left aside since the 1370s. The formidable text would only be plucked from obscurity by the 'last Medieval philosopher' - Nicholas of Cusa - in the 1450s. Cusa's great concordance project went to great lengths to make sure that probably this best commentary on Neoplatonism from the whole of the Middle Ages survived into the Renaissance. However, next to Cusa stood two eminent Dutch thinkers, both with a deep connection to Cologne, who themselves contributed significantly and in equally original fashion to the reception of Neoplatonism in the later Middle Ages. The profits of Berthold's project should, therefore, in conclusion be read in juxtaposition with the works of Heymeric and Denys.

\section{The Neoplatonic perspectives of Heymeric of Camp (1395-1460)}

Berthold's contribution to the development of the Cologne tradition was succeeded by Heymeric of Camp, (1395-1460; also Heymericus de Campo and Heymerik van de Velde), a leading Albertist scholar from Cologne in the 15th century and like Denys de Leeuwis (infra), he hailed from the Netherlands. Heymeric was a master in theology at Cologne and the author of more than 30 philosophical and theological works, of which tragically few were printed or have been edited up to now. He served as rector of Cologne and represented the university at the turbulent council of Basel (1432-1435). Heymeric was for a short period (1425-1426) a teacher of Cusa at Cologne and the academic connection between the two thinkers developed over the years into a committed friendship (it was probably Heymeric who introduced Cusa to Ramon Lull's [1232-1316] idiosyncratic texts, which became crucial for Cusa's concordance project [Ziebart 2011:475]). Like Albert, Ulrich, Dietrich and Berthold, Heymeric's thought was at home within Neoplatonic scholasticism, again not only influenced by Albert but also by Lull's Ars generalis (Colomer 1963:216-220). Born in the vicinity of Eindhoven, the young Dutchman entered the University of Paris around 1415, where he obtained the baccalaureus in arts and went to Louvain to lecture philosophy, in anticipation of the establishment of the university there (in 1425). He returned to Cologne the next year to engage in postgraduate studies in theology. On the strength and basis of a first work in metaphysics he had already completed at the time, titled Compendium divinorum, he was immediately allowed into the Dominicans' faculty of theology, where he was promoted to magister in 1428 and offered a professorship shortly thereafter. From 1432 to 1435 he served with distinction as rector of Cologne but decided at the end of 1435 to return to Louvain to assist in the development of the young university's theological faculty. He lived and worked in Louvain up to 1453. Although he wrote the Compendium divinorum before he doctorated, it still is Heymeric's most known and possibly most important work, because his Neoplatonic orientation is herein better clarified than in any of his successive works. 
Compendium divinorum presents yet another Neoplatonic view on reality, in terms of which all of creation is characteristically explained as the overflow and descent of the hierarchical-highest first principle to lower and sequential principles. Heymeric, however, argues in unique fashion that the internal structure of the cosmos reflects an image of the first principle and, therefore, must be triadic in nature. Every substance in the cosmos is an independent unit, but carries in itself the triadic structure, where esse, posse and operari correspond to the Trinitarian Persons' being, potentiality and action. This triadic model is elaborated on in a second significant work, Theoremata totius universi, where several other triadic structures are further explored, for instance unitas [unity], veritas [truth] and bonitas [the good]. A third work, Tracatus de sigillo aeternitatis [written during his rectorship in Cologne], describes the Godhead according to a Lullian circle of unity (Beukes 2020a:II:835-843). In the same period Heymeric wrote an extensive introduction to philosophy, Colliget principiorum iuris naturalis, divini et humani philosophice doctrinalium, followed by the short Ars demonstrativa, in which the Aristotelian principle of non-contradiction is employed to develop a theory to indicate the validity of both philosophical and theological truth claims, precisely by indicating the absurdity of the opposite of such claims. Another distinguished work was the De signis notionalibus, written at the theological faculty in Louvain. Here Heymeric returns to the Neoplatonic and triadic structures he already developed in the Compendium divinorum.

Heymeric's last work, however, places the crown on the former Colognian's scholarly work: the Centheologicum, written shortly before his retirement at Louvain, is a broad compilation and analysis of 100 philosophical works (hence the title), generally from the 15th century, amongst which texts by his friend Cusa and the unique philosophy of Lull (Imbach 1983:475). These works have in common that they investigate the possibility of universal knowledge, which have application value in both philosophy and theology, with the main feature being the unique triadic structure presented therein. Apart from the works in philosophy, Heymeric also left numerous works of theology, including a commentary on Lombard's Sententiae (Hoenen 2002:513-515), as well as short commentaries on Aristotelian logic, natural philosophy and ethics (which in the Middle Ages always included political theory). As solid as Heymeric's contribution to development of the Cologne tradition in the later Middle Ages was, it was in terms of brute volume overshadowed by the encyclopaedic labour of his Cologne-Dutch contemporary, Denys de Leeuwis.

\section{The encyclopaedic contribution of Denys de Leeuwis (1402-1471)}

Denys de Leeuwis, ${ }^{7}$ with the sobriquet Doctor Extaticus (or otherwise Dionysius der Kartäuser and Denys the Carthusian), was a contra-nominalist and encyclopaedic Neoplatonic Thomist from the Netherlands in the late 15th century: 'Encyclopaedic', because this Carthusian monk was in terms of erudition and original outputs (with more than 150 surviving texts) a shining example of philosophical scholarship at the time. Born in Rijkel in the Belgian province of Limburg, the young Denys was educated in the convent school of Saint-Truiden, after which he matriculated at the famous gimnasuim in Zwolle in the Netherlands. Already in Zwolle Denys was introduced to the Devotia Moderna, a reformation movement from the later Middle Ages that advocated an evangelical and apostolic life. The roots of the movement go back to female religious movements in the high Middle Ages, but as a movement it only gained momentum from 1378, in particular as a critical reaction against excesses in the church (notably in the polarised papacy during the Great Schism of 1378 to 1417; Beukes 2021:3-4). Denys was profoundly influenced by the Devotia Moderna and contributed significantly to its progression in the 15th century, whilst always carrying its critical spirit with him from Cologne to Roermond.

Different from other orders in the Middle Ages (with exception of the Cistercians), the Carthusians insisted on not allowing boys into the order. Denys, then aged 13, himself was on grounds of age refused entry to the order in 1415 . He then left, on advice of the monastery management at the Carthusian's seat in Roermond, for the University of Cologne, now merely three decades old, where he graduated in arts in 1421 with a scholarship provided by the Dominicans. This university, which as indicated maintained strong ties with the Dominicans from the time Albert established the studium there in the 1240s, held the Carthusians in high regard, because the Ordo Cartusiensis itself had intimate historical ties with the city of Cologne (the Carthusian order was established on 15 August 1084 by Bruno of Cologne). ${ }^{8}$ Knowing that Denys explicitly wanted entry to the Carthusian order and did not consider becoming a Dominican, the authorities in Cologne allowed the young post-graduate to develop within the Albertist and Thomist sub-cultures at the university. Denys was promoted to magister in arts in 1424, after which he returned to the monastery in Roermond in the south-east of the Netherlands. On his return, the Carthusians granted him immediate entry to the order: Denys would live and work the rest of his life at this monastery in Roermond, except for the 4 years before his death in 1471, when he established the Carthusians' new monastery in Vught close to Hertogenbosch. Like Heymeric, Denys had close relations with Cusa and the two philosophers commented on each other's work regularly. At least three of Denys' works are dedicated to Cusa or can be associated with him (Emery 2006:243; Palazzo 2011:258). It was precisely the influence of the more cosmopolitan Cusa that refrained Denys' from intellectual isolation in Roermond; Cusa took care that Denys not only stayed in touch with a broad socio-historical context, but indeed maintained dialogue with his alma mater in Cologne, to the effect that Denys'

8.For excellent elaborations on the development of the order of the Carthusians, see Hogg (2014:32-38) and Pansters (2014:15-18). 
works reflect the complete spectrum of the academic milieu of the 15th century, including cloister mysticism, Neoplatonic philosophy, scholastic theology and an eloquent support for the Devotia Moderna. Denys also accompanied Cusa on his journey as cardinal of the pope in the Low Countries in 1451 and 1452.

Because of his formidable intellect Denys was often approached by both the secular and ecclesiastical authorities for advice on several issues, with specific reference to the proto-Reformation contents of his vast array of texts. The more than 150 extant texts, which are still attributed to Denys without dispute, stage him as probably the most productive author in Medieval philosophy, even in comparison with Aquinas' Summa Theologiae, which comprises 61 volumes (Emery 2006:243). Aquinas' summa is volume wise indeed more extensive as the sum of Denys' extant corpus (although it is uncertain how many of Denys' texts did not survive; Emery 1998:668), yet Denys' oeuvre presents thematically and in terms of the relevant genres a more extensive register, even when Aquinas' works beyond the summa are taken into consideration. It took the monks of the Ordo Cartusiensis almost four decades of intense edition-critical labour to revise Denys' outputs in 42 volumes during the first decades of the 20th century.

Denys De Leeuwis (1896-1935) left Biblical commentaries on virtually all 66 canonised Biblical texts, commentaries on monastery discipline (which include the commentary $\mathrm{Ad}$ stilum facillimum on John Cassian's Collationes, as the patristic predecessor of the Ordo Cartusiensis), mystical, ascetic, pastoral, juridic, reforming and apologetic texts, as well as more than 900 sermons and a summa (uncommon for the 15th century, titled Summa de vitiis et virtutibus; Emery 2006:243). Yet, his commentary on Lombard's Sententiae is the most extensive; against the convention at the time to produce only shorter and selective commentaries on the Sententiae (by addressing only one or two of the original four volumes of Lombard's work), Denys opted to make a life project of it. He concluded the work in 1464, after working for four decades on it since his promotion to magister at Cologne. Stylistically the work differs from the many other Sententiae-commentaries in Medieval academic history (since the end of the 12th century a solid commentary on the Sententiae was a prerequisite to be promoted to magister in theology at any noteworthy university), in the sense that Denys comments every proposition in the Sententiae, then juxtaposing it as an evaluation with the most significant texts from the 13th to the 15 th century, after which he revises his initial comments. His choice for realism against nominalism is also stressed throughout; Denys considers 'nominalists' such as Ockham unable to postulate anything meaningful about the lived lives of individuals and, therefore, engages in intense contranominalism debates with the Ockhamists of the 15th century. In addition, Denys commented on the whole set of PseudoDionysius' Corpus Dionysiacum, eventually comprising several volumes on Dionysius' De Divinis Nominibus (On Divine Names), De Mystica Theologia (On mystical theology), De Coelesti Hierarchia (On celestial hierarchy), De Ecclesiastica
Hierarchia (On ecclesiastical hierarchy) and Epistulae (Letters). This he followed up with an extensive commentary on all Boethius' extant texts, with accent on a 15th-century reappraisal of De consolatione Philosophiae. An outspoken Cologne Thomist, Denys' commentary on Aquinas' summa itself consists of several volumes.

Yet, it is Denys' independent, original philosophical and theological works wherein he synthesises his unique perspectives in above-mentioned works that draw most attention. The first of these synthetic works is the De lumine christiane theoriae (1452), which is also Denys' most extensive work in this genre. Here he works like his predecessors Ulrich, Dietrich, Berthold and Dutch contemporary Heymeric with a Neoplatonic teaching on creation, again employing overflowing, descending emanation and returning reditus as its core principle. The difference to these predecessors is, however, that Denys engages literally every Medieval thinker who worked with this principle, including all the thinkers of antiquity and the Jewish and Arabic thinkers available to him in the 15th century. This explains the conceptual extent of the work, which again comprises several volumes. With his indexing and annotation of all the most important philosophical issues since Plato and Aristotle, via Middle Platonism, Neoplatonism, patrology, Augustine, Boethius, Pseudo-Dionysius and the thinkers that followed them, it is clear that Pseudo-Dionysius remains his source of preference. He probably wrote the Dionysic Elementatio philosophica only after completing the Sententiae-commentary in 1464, followed up with a similar work regarding theological questions (Elementatio theologica). It is significant, and Berthold's significance is hereby stressed, that both these works were structured on Berthold's blueprint of Proclus' Elementatio theologica (Palazzo 2011:259).

Denys' sources are not less extensive than his corpus itself; apart from the 66 canonical texts, his literature includes commentaries on the Western fathers, the Medieval mystical thinkers (including the female thinkers he had access to) and the early- and high-scholasticism from the 11th to the middle of the 14th century. Yet it is clear that Denys, his high regard for Aquinas and his academic upbringing in the via Thomae notwithstanding, considered the Dionysic corpus as the most authoritative source for 15th century philosophical reflection, according to which all other philosophical systems should be evaluated, both in the theological and philosophical disciplines. In fact, the later Denys of the 1460s took leave of Aquinas on crucial points, without distancing himself from the Thomist tradition as such (Emery 1998:670-679). Like Berthold, Denys must, therefore, be described as a Cologne exponent of Neoplatonic mysticism from the later Middle Ages.

The Dionysic notion of a hierarchic wisdom structure takes central stand in virtually all of Denys' texts, according to which philosophy has a preparatory function; philosophy prepares the human intellect for the superior modi of transcendent forms of knowledge, which culminate in the highest form of philosophy, namely metaphysical-contemplative thought. 
The object of thought in metaphysical-contemplative reflection is the primum movens or first mover, as well as the distinguishable substances, which transcend every immanent cause in the natural world. In opposition to the majority of Carthusians, Denys hereby questions an exclusively affective interpretation of the mystical unification between God and the human subject. He rather argues consistently for the development of a cognitive interpretation of such unification.

Denys' interpretation of Dionysius falls back on a unique secondary source from the 14th century, in the Dionysic appraisals of a Dutch predecessor, the alter Dionysius, Jan van Ruusbroec (Beukes 2020d:1-7). He incorporates a fundamental aspect of Ruusbroec's mystical theology, namely that the mind by metaphysical contemplation is able to unite with God by knowing the otherwise impenetrable light of God quia est, yet only when the mind can succeed in breaking through the immanence of the mind. The soul follows the intellect when the soul is affectively united with God, because the element of love in free will as a faculty of the soul guides this cognitive act (Macken 1984:1-10). From this premise Denys' general focus on the nature and operations of the rational soul is developed. Under the influence of Dionysius, Albert, Ulrich and Berthold, Denys posits theories wherein Aquinas is implicitly but effectively critiqued. He argues, for example, that the mind has unmediated access to the phantasms, that the mind can know the quiddity of independent substances without mediation and through both the mind is enabled to know God quia est (Palazzo 2004b:163-168) - all views that Aquinas would have rejected outright.

Given the interaction between the order of being and the order of knowability, Denys interprets Aquinas' denial of the soul's ability to know God independent of the corporality of the soul as effectively an argument against the immortality of the soul. As knowledge independent of phantasms was one of the key differences between the Albertists and Thomists in Cologne, Denys hereby sides with the Albertists (Palazzo 2011:260). Denys also targets the distinction between essence and existence in Aquinas' thought: where he as a young master in Cologne still maintained Aquinas' position in this regard in terms of a real distinction between esse and essentia, the later Denys, precisely because of the influence of the Neoplatonists Albert, Ulrich and Berthold, argues that the distinction between essence and existence is not real, but intentional. In this regard, Denys positioned himself again closer to the Albertists and Berthold's legacy in particular than to the Thomists.

\section{Conclusion}

When Berthold of Moosburg's unique Neoplatonist interpretation is related to the Cologne tradition, as the cornerstone of the distinctive role Neoplatonism played in later Medieval intellectual trajectories, with Albert and Aquinas as its main exponents and Ulrich, Dietrich, Heymeric and Denys as its secondary exponents, the Cologne centre of
Neoplatonism is significantly expanded and enriched. The aim of this article, to present a fresh and reworked overview of Neoplatonist developments in the Cologne tradition of the later Middle Ages, with direct reference to Berthold's Proclian commentary, situating him in the post-Eckhart Dominican crisis, regarding his indebtedness to the Dominicans Albert, Ulrich and Dietrich and his Dutch-Cologne successors, Heymeric and Denys, shows that Berthold's unique contribution to the philosophical discourse of the Middle Ages is established therein that his Expositio provided a synthesis of Neoplatonism and contemporaneous German-Dominican theories. By contextualising the work of his Cologne predecessors and successors in the broad idea-historical landscape of antiquity and Neoplatonism, it is clear that Berthold succeeded in linking the vast Neoplatonic legacies in Medieval philosophy with Cologne Albertism, thereby providing an impetus for the overall consolidating and surviving ability of the Cologne tradition. By juxtaposing the idiosyncratic Berthold and his Expositio with the more conventional legacies of Ulrich, Dietrich, Heymeric and Denys, this exceptional Latin-Western intellectual tradition from Cologne is hereby magnified, in all its Neoplatonic lavishness. By the grace of these thinkers, there is still a 'continental', 'Western' and indeed comprehensible Medieval history of ideas alive today. The 'Enlightenment' darkened much, but not authentic scholarship in philosophy. Berthold, his tradition and intellectual extension, constitute a proof thereof.

\section{Acknowledgements}

The author is an associate of the Center for the History of Philosophy and Science (CHPS), Radboud University Nijmegen, The Netherlands.

\section{Competing interests}

The author declares that he has no financial or personal relationship(s) which may have inappropriately influenced him in writing this article.

\section{Author's contribution}

J.B. is the sole author of this article.

\section{Ethical considerations}

The author confirms that ethical clearance was not required for the study.

\section{Funding information}

The Department of Philosophy, Faculty of Humanities, University of the Free State, funded all page and publication fees for this article.

\section{Data availability}

Data sharing is not applicable to this article as no new data were created or analysed in this study. 


\section{Disclaimer}

The views and opinions expressed in this article are those of the author and do not necessarily reflect the official policy or position of any affiliated agency of the author.

\section{References}

Aertsen, J.A., 1996, 'Albertus Magnus und die mittelalterliche Philosophie', Allgemeine Zeitschrift für Philosophie 1, 111-128.

Aertsen, J.A., 1999, 'Die Transzendentalienlehre bei Dietrich von Freiberg', in K.-H. Kandler, B. Mojsisch \& F.-B. Stammkötter (eds.), Dietrich von Freiberg. Neue Perspektiven seiner Philosophie, Theologie und Naturwissenschaft, pp. 23-47, B.R. Grüner, Amsterdam.

Aertsen, J.A., 2013, 'Albert's doctrine on the transcendentals', in I.M. Resnick (ed.), $A$ companion to Albert the Great. Theology, philosophy and the sciences, pp. 611-618, Brill, Leiden.

Albert, 1960, Metaphysica, Colon XVI/1 edn., Aschendorff, Münster.

Albert, 1968, De anima, Colon VII/1 edn., Aschendorff, Münster.

Albert, 1980, De causis proprietatum elementorum, Colon V/2 edn., Aschendorff, Münster.

Albert, 1987, Physica, Colon IV/1 edn., Aschendorff, Münster.

Anzulewicz, H., 2013a, 'Anthropology: The concept of man in Albert the Great', in I.M. Resnick (ed.), A Companion to Albert the Great. Theology, philosophy and the sciences, pp. 325-346, Brill, Leiden.

Anzulewicz, H., 2013b, 'Plato and platonic/Neoplatonic sources in Albert', in I.M. Resnick (ed.), A companion to Albert the Great. Theology, philosophy and the sciences, pp. 595-600, Brill, Leiden.

Ansulewicz, H., 2019, 'Berthold of Moosburg's theory of intellect: Re-thinking the continuity of the tradition of Albert the Great', in The retrieval and renewal of medieval metaphysics: Berthold of Moosburg's commentary on Proclus' elements of theology, Conference held at University College Dublin, October 23-25, pp. 1-14.

Aristoteles, 1995, 'Categoriae', in J. Barnes (ed.), The complete works of Aristotle, trans. J.L. Ackrill, pp. 3-25, Princeton University Press, Princeton, NJ.

Armstrong, A.H., 1962, Plotinus, Collier Books, New York, NY.

Backes, I., 1935, Die Christologie, Soteriologie und Mariologie des Ulrich von Strassburg: Ein Beitrag zur Geistesgeschichte des 13. Jahrhundert, vols. I \& II, Paulinus-Verlag, Trier.

Bertolacci, A., 2013, 'Albert's use of Avicenna and Islamic philosophy', in I.M. Resnick (ed.), A companion to Albert the Great. Theology, philosophy and the sciences, pp. 601-610, Brill, Leiden.

Beukes, J., 2018a, "n Herlesing van Pseudo-Dionisius se metafisika', HTS Teologiese Studies/Theological Studies 74(4), Art. \#5111, 1-9. https://doi.org/10.4102/ hts.v74i4.5111

Beukes, J., 2018b, 'Dionisiese spore in Kusa se metafisika', HTS Teologiese Studies/ Theological Studies 74(4), Art. \#5112, 1-8. https://doi.org/10.4102/hts.v74i4.5112

Beukes, J., 2018c, 'Die Arabiese trajek in die Karolingiese periode in Middeleeuse filosofie', Litnet Akademies 15(3), 502-564, viewed 15 June 2020, from https://www.
litnet.co.za/wp-content/uploads/2018/12/LitNet_Akademies_15-3_ litnet.co.za/wp-cont
Beukes_502-564.pdf.

Beukes, J., 2018d, 'Die Arabiese trajek in die post-Karolingiese periode in Middeleeuse filosofie', Litnet Akademies 15(3), 565-626, viewed 15 June 2020, from https://www. filosofie', Litnet Akademies 15(3), 565-626, viewed 15 June 2020, from https://wWw.
litnet.co.za/wp-content/uploads/2018/12/LitNet_Akademies_15-3 litnet.co.za/wp-cont
Beukes_565-626.pdf.

Beukes, J., 2019, “"Maak die wêreld nie tot bespotting nie”: ' $n$ Herwaardering van die filosofiese aspekte in Mechtild von Magdeburg se Das fließende Licht der Gottheit (1250)', Verbum et Ecclesia 40(1), Art. \#1965, 1-8. https://doi.org/10.4102/ ve.v40i1.1965

Beukes, J., 2020a, Middeleeuse Filosofie, vols. I \& II, Akademia, Pretoria.

Beukes, J., 2020b, 'Die eliminering van die siel in die filosofiese mistiek van die begyn Marguerite Porete (1250-1310)', Litnet Akademies 17(2), viewed 15 June 2020, from https://www.litnet.co.za/die-eliminering-van-die-siel-in-die-filosofiesemistiek-en-negatiewe-teologie-van-die-begyn-marguerite-porete-1250-1310/.

Beukes, J., 2020c, 'The Trinitarian and Christological Minnemystik of the Flemish beguine Hadewijch of Antwerp (fl.1240)', HTS Teologiese Studies/Theological Studies 76(1), Art. \#5865, 1-10. https://doi.org/10.4102/hts.v76i1.5865

Beukes, J., 2020d, 'Die triomf van 'n post-skolastieke mistiek oor skolastieke lojalisme: Gersonius versus Ruusbroec (postuum), 1399', HTS Teologiese Studies/Theological Studies 76, Art. \#5672, 1-12. https://doi.org/10.4102/hts.v76i1.5672

Beukes, J., 2021, 'Die "vyf trane" as mistieke uitdrukking in die Dialoë van die Dominikaanse non Katharina van Siena (1347-1380)', Litnet Akademies 18. (In publication).

Birkenmajer, A., 1922, 'Drei neue Handschriften der Werke Meister Dietrichs', Beiträge zur Geschichte der Philosophie des Mittelalters 20(5), 70-90.

Boese, H., 1985, Wilhelm von Moerbeke als Übersetzer der Stoicheiosis Theologike des Proclus, Bitsch, Heidelberg.

Bonin, T., 2001, Creation as emanation. The origin of diversity in Albert the Great's on the causes and the procession of the universe, University of Notre Dame Press, Notre Dame, IN.
Colomer, E., 1963, 'Heimeric van de Velde entre Ramón Llull y Nicolas de Cusa', in J. Vincke (ed.), Spanische Forschungen der Görres-Gesellschaft, vol. 21, pp. 216-232, Aschendorff, Münster.

Copleston, F.C., 1993, A history of philosophy, volume II, medieval philosophy, Doubleday, New York, NY.

Courtenay, W.J., 1989, 'Theologia Anglicana Modernorum at Cologne in the fourteenth century', in A. Zimmermann (ed.), Die Kölner Universität im Mittelalter: Geistige Wurzeln und soziale Wirklichkeit, Miscellanea Mediaevalia, vol. 20, pp. 245-254, Walter de Gruyter, Berlin.

De Leeuwis, D., 1896-1935, Opera Omnia, Monks of the Carthusian Order (eds.), vols. I-XXXXII, Analecta Cartusiana, Saint-Etienne.

Dillon, J., 1990, The golden chain. Studies in the development of Platonism and Christianity, Variorum, London.

Dreyer, M., 2006, 'Albertus Magnus', in J.J.E. Gracia \& T.B. Noone (eds.), A companion to philosophy in the middle ages, pp. 92-101, Blackwell, Oxford.

Emery, K., 1990, 'Did Denys the Carthusian also read Henricus Bate?', Bulletin de Philosophie Médiévale 32, 230. https://doi.org/10.1484/J.BPM.3.420

Emery, K., 1998, 'The matter and order of philosophy according Denys the Carthusian', in J.A. Aertsen \& A. Speer (eds.), Was ist Philosophie im Mittelalter? Miscellanea Mediaevalia, vol. 26, pp. 667-679, Walter de Gruyter, Berlin.

Emery, K., 2006, 'Denys the Carthusian', in J.J.E. Gracia \& T.B. Noone (eds.), A companion to philosophy in the middle ages, pp. 258-260, Blackwell, Oxford.

Flasch, K., 1972, 'Kennt die mittelalterliche Philosophie die konstitutive Funktion des menschlichen Denkens? Eine Untersuchung zu Dietrich von Freiberg', Kant-Studien 63, 182-206. https://doi.org/10.1515/kant.1972.63.1-4.182

Flasch, K., 1985, 'Von Dietrich zu Albert', Freiburger Zeitschrift für Philosophie und Theologie 32, 7-26.

Führer, M., 1999, 'The agent intellect in the writings of Meister Dietrich of Freiberg and its influence on the Cologne school', in K.-H. Kandler, B. Mojsisch \& F.-B. Stammkötter (eds.), Dietrich von Freiberg. Neue Perspektiven seiner Philosophie, Theologie und Naturwissenschaft, pp. 69-88, B.R. Grüner, Amsterdam.

Führer, M. \& Gersh, S., 2014, 'Dietrich of Freiberg and Berthold of Moosburg', in S.E. Gersh (ed.), Interpreting Proclus. From antiquity to the renaissance, pp. 299-317, Cambridge University Press, Cambridge.

Führer, M.L. (intr. \& transl.), 1992, Dietrich of Freiberg: Treatise on the intellect and the intelligible, Marquette University Press, Milwaukee, WI.

Gersh, S., 1986, Middle Platonism and Neoplatonism. The Latin tradition, vol. II, University of Notre Dame Press, Notre Dame, IN.

Gersh, S., 2001, 'Berthold of Moosburg and the content and method of Platonic philosophy', in J.A. Aertsen, K. Emery \& A. Speer (eds.), Philosophie und Theologie an der Universität von Paris im letzen Viertel des 13. Jahrhunderts, pp. 493-503, an der Universität von Paris
Walter de Gruyter, Berlin.

Gersh, S., 2002, 'The medieval legacy from ancient Platonism', in S. Gersh \& M.J.F.M. Hoenen (eds.), The Platonic tradition in the middle ages. A doxographic approach, pp. 3-30, Walter de Gruyter, Berlin.

Gersh, S., 2014, Being different. More Neoplatonism after Derrida, Brill, Leiden.

Gersh, S., 2019, 'Introduction', in S. Gersh (ed.), Plotinus' legacy: The transformation of Platonism from the renaissance to the modern era, pp. 1-16, Cambridge University Press, Cambridge.

Gerson, L.P., 1994, Plotinus, Routledge, London.

Goris, W., 1999, 'Dietrich von Freiberg und Meister Eckhart über das Gute', in K.-H. Kandler, B. Mojsisch \& F.-B. Stammkötter (eds.), Dietrich von Freiberg. Neue Perspektiven seiner Philosophie, Theologie und Naturwissenschaft, pp. 169-188, B.R. Grüner, Amsterdam.

Haren, M., 1985, Medieval thought. The Western intellectual tradition from antiquity to the thirteenth century, Macmillan, London.

Heiduk, M., 2012, 'Offene Geheimnisse - Hermetische Texte und verborgenes Wissen in der mittelalterlichen Rezeption von Augustinus bis Albertus Magnus', Published dissertation, Faculty of Philosophy, University of Freiburg.

Hendrix, S.E., 2010, How Albert the Great's Speculum Astronomiae was interpreted and used by four centuries of readers, The Edwin Mellen Press, New York, NY.

Hoenen, M.J.F.M., 2002, 'Academic theology in the fifteenth century: The Sentences commentary of Heymericus de Campo', in P.J.J.M. Bakker (ed.), Chemins de la Pensée Médiévale. Études offertes à Zénon Kaluza, E. Faye \& C. Grellard (co-eds.), pp. 513-519, Brepols, Turnhout.

Hogg, J., 2014, 'The Carthusians: History and heritage', in K. Pansters (ed.), The Carthusians in the low countries: Studies in monastic history and heritage, Miscellanea Neerlandica XLIII: Studia Cartusiana, pp. 31-56, Peeters Publishers, Louvain.

Imbach, R., 1983, 'Das Centheologicon des Heymericus de Camp und die darin enthaltenen Cusanus-Reminisizenzen: Hinweise und Materialen', Traditio 39, 466-477. https://doi.org/10.1017/S0362152900009727

Iremadze, T., 2004, Konzeptionen des Denkens im Neoplatinismus: Zur Rezeption der Proklischen Philosophie im Deutschen und Georgischen Mittelalter. Dietrich von Froiberg, Berthold von Moosburg, Joane Petrizi, Gruner, Amsterdam.

Jeck, U.R., 1999, 'Der Spruch des Apollophanes. Dietrich von Freiberg über PseudoDionysius Areopagita in der Schrift De cognitione entium separatorum. Ein Beitrag zur Diskussion kosmologischer Paradoxien im Mittelalter', in K.-H. Kandler, B. Mojsisch \& F.-B. Stammkötter (eds.), Dietrich von Freiberg. Neue Perspektiven seiner Philosophie, Theologie und Naturwissenschaft, pp. 89-119, B.R. Grüner, Amsterdam.

Kandler, K.-H., 1998, 'Theologie und Philosophie nach Dietrich von Freibergs Traktat, De subiecto theologiae', in J.A. Aertsen \& A. Speer (eds.), Was ist Philosophie im Mittelalter? Miscellanea Mediaevalia, vol. 26, pp. 642-647, Walter de Gruyter, Berlin. 
King, E., 2018, 'Berthold of Moosburg on intellect and the one of the soul', Dionysius 32, 184-199.

Klibansky, R., 1928-9, 'Ein Proklos-Fund und seine Bedeutung', in Sitzungsberichte der Heidelberger Akademie der Wissenschaft, Philosophisch-historische Klasse, pp. 1-41, Heidelberg.

Kobusch, T., 1987, 'Die Modi des Seienden nach Dietrich von Freiberg', in K. Flasch (ed.), Von Meister Dietrich zu Meister Eckhart, pp. 46-67, Felix Meiner, Hamburg.

Krebs, E., 1906, 'Meister Dietrich. Sein Leben, seine Werke, seine Wissenschaft', Beiträge zur Geschichte der Philosophie des Mittelalters V, 5-6.

Largier, N., 1999, 'Negativität, Möglichkeit und Freiheit. Zur Differenz zwischen de Philosophie Dietrichs von Freiberg und Ekcharts von Hochheim', in K.-H. Kandler, B. Phosisch \& B. Stammö̈ter (eds.), Dietrich von Freberg. Neue Perspektiven seiner Mojsisch \& F.-B. Stammkotter (eds.), Dietrich von Freiberg. Neue Perspektiven seiner
Philosophie, Theologie und Naturwissenschaft, pp. 149-168, B.R. Grüner, Amsterdam.

Löhr, G.M., 1946, Die Kölner Dominikanerschule vom 14. bis zum 16. Jahrhundert, i.B., Freiburg.

Macken, R., 1984, 'Denys the Carthusian, commentator on Boethius' De consolatione philosophiae', Analecta Cartusiana 118, 1-70.

Mahoney, E.P., 1982, 'Sense, intellect and imagination in Albert, Thomas and Siger', in N. Kretzmann, A. Kenny \& J. Pinborg (eds.), The Cambridge history of later medieval philosophy, pp. 602-622, Cambridge University Press, Cambridge.

Maurer, A., 1956, 'The De quidditatibus entium of Dietrich of Freiberg and its criticism of Thomistic metaphysics', Mediaeval Studies 18, 172-203. https://doi. org/10.1484/J.MS.2.306609

Merlan, P., 1968, From Platonism to Neoplatonism, Nijhoff, The Hague.

Milem, B., 2006, 'Berthold of Moosburg', in J.J.E. Gracia \& T.B. Noone (eds.), $A$ companion to philosophy in the middle ages, pp. 215-216, Blackwell, Oxford.

Moosburg, B., 1984-2007, Expositio super Elementationem theologicam Procli, vols. I-IX, L. Sturlese et al. (eds.), Felix Meiner Verlag, Hamburg.

Mojsisch, B., 1987a, 'Causa essentialis bei Dietrich von Freiberg und Meister Eckhart' in K. Flasch (ed.), Von Meister Dietrich zu Meister Eckhart, pp. 106-114, Felix Meiner, Hamburg.

Mojsisch, B., 1987b, 'Sein als Bewußt-Sein. Die Bedeutung des ens conceptionale be Dietrich von Freiberg', in K. Flasch (ed.), Von Meister Dietrich zu Meister Eckhart pp. 95-105, Felix Meiner, Hamburg.

Noone, T.B., 2013, 'Albert on the subject of metaphysics', in I.M. Resnick (ed.), $A$ companion to Albert the Great. Theology, philosophy and the sciences, pp. 543-552, Brill, Leiden.

O'Donnell, J.R. (red.), 1955, Nine medieval thinkers: A collection of hiterto unknown texts, Pontifical Institute of Mediaeval Studies, Toronto.

O'Meara, D.J., 1995, Plotinus: An introduction to the enneads, Clarendon Press, Oxford.

Mynors, R.A.B., 1963, Catalogue of the manuscripts of Balliol College Oxford, Clarendon Press, Oxford.

Palazzo, A., 2004a, 'Ulrich of Strasbourg and Denys the Carthusian (I): Textual analysis and doctrinal comments', Bulletin de Philosophie Médiévale 46, 61-113. https:// doi.org/10.1484/J.BPM.2.303884

Palazzo, A., 2004b, 'Ulrich of Strasbourg and Denys the Carthusian (II): Doctrinal influence and implicit quotations', Bulletin de Philosophie Médiévale 48, 163-208. https://doi.org/10.1484/J.BPM.2.303203
Palazzo, A., 2011, 'Denys the Carthusian', in H. Lagerlund (ed.), Encyclopaedia of medieval philosophy - Philosophy between 500 and 1500, pp. 258-260, Springer, London.

Palazzo, A., 2019, 'Berthold of Moosburg's concept of providence', in The retrieval and renewal of medieval metaphysics: Berthold of Moosburg's commentary on Proclus' elements of theology, Conference held at University College Dublin, October 23-25, pp. 1-11.

Pansters, K., 2014, 'Introduction', in K. Pansters (ed.), The Carthusians in the low countries: Studies in monastic history and heritage, Miscellanea Neerlandica XLIII: Studia Cartusiana, pp. 11-29, Peeters Publishers, Louvain.

Resnick, I.M., 2013, 'Albert the Great: Biographical introduction', in I.M. Resnick (ed.) A companion to Albert the Great. Theology, philosophy and the sciences, pp. 1-14, Brill, Leiden.

Sannino, A., 2000, 'Berthold of Moosburg's hermetic sources', Journal of the Warburg and Courtauld Institutes 63, 243-258. https://doi.org/10.2307/751527

Strasbourg, U., 1955, 'Summa de Bono of Ulrich of Strasbourg', in J.R. O'Donnell (ed.), Nine medieval thinkers: A collection of hiterto unknown texts, pp. 293-307, Pontifical Institute of Mediaeval Studies, Toronto.

Sturlese, L., 2007, 'Homo divinus. Der Prokloskommentar Bertholds von Moosbrug und die Probleme der nacheckartschen Zeit', in L. Sturlese (ed.), Homo divinus. Philosophische Projekte in Deutschland zwischen Meister Eckhart und Heinrich Seuse, pp. 137-154, Kohlhammer, Stuttgart.

Synan, E.A., 1980, 'Albertus Magnus and the sciences', in J.A. Weisheipl (ed.), Albertus Magnus and the sciences, pp. 1-12, Pontifical Institute of Mediaeval Studies, Toronto.

Tarrant, H., 2011, From the old academy to later Neoplatonism, Variorum, Ashgate.

Tracey, M.J., 2013, 'The moral thought of Albert the Great', in I.M. Resnick (ed.), A companion to Albert the Great. Theology, philosophy and the sciences, pp. 347-380, Brill, Leiden.

Twetten, D. \& Baldner, S., 2013, 'Introduction to Albert's philosophical work', in I.M. Resnick (ed.), A companion to Albert the Great. Theology, philosophy and the sciences, pp. 165-172, Brill, Leiden.

Wagner, M.F., 2008, The enigmatic reality of time: Aristotle, Plotinus, and today, Brill, Leiden.

Wassermann, D., 1996, Dionysius der Kartäuser: Einführung in Werk und Gedenkenwelt, Analecta Cartusiana, Saint-Etienne.

Weisheipl, J.A., 1980, 'The life and works of St Albert the Great', in J.A. Weisheipl (ed.) Albertus Magnus and the sciences, pp. 13-25, Pontifical Institute of Mediaeval Studies, Toronto.

Zambelli, P., 1992, The Speculum Astronomiae and its enigma. Astrology, theology and science in Albertus Magnus and his contemporaries, Kluwer, Dordrecht.

Zavaterro, I., 2011a, 'Berthold of Moosburg', in H. Lagerlund (red.), Encyclopaedia of medieval philosophy - Philosophy between 500 and 1500, pp. 163-165, Springer, London.

Zavaterro, I., 2011b, 'Ulrich of Strasbourg', in H. Lagerlund (red.), Encyclopaedia of medieval philosophy - Philosophy between 500 and 1500, pp. 1351-1356, Springer, London.

Ziebart, K.M., 2011, 'Heymeric of camp', in H. Lagerlund (red.), Encyclopaedia of medieval philosophy - Philosophy between 500 and 1500, pp. 473-476, Springer, London. 